\title{
BAHASA ARAB DALAM BAHASA INDONESIA (Analisis Kritis terhadap Perubahan Makna Kata Serapan Bahasa Arab)
}

\author{
Afjalurrahmansyah \\ (Mahasiswa Pascasarjana UIN Alauddin Makassar) \\ Afjalelfarisy@gmail.com
}

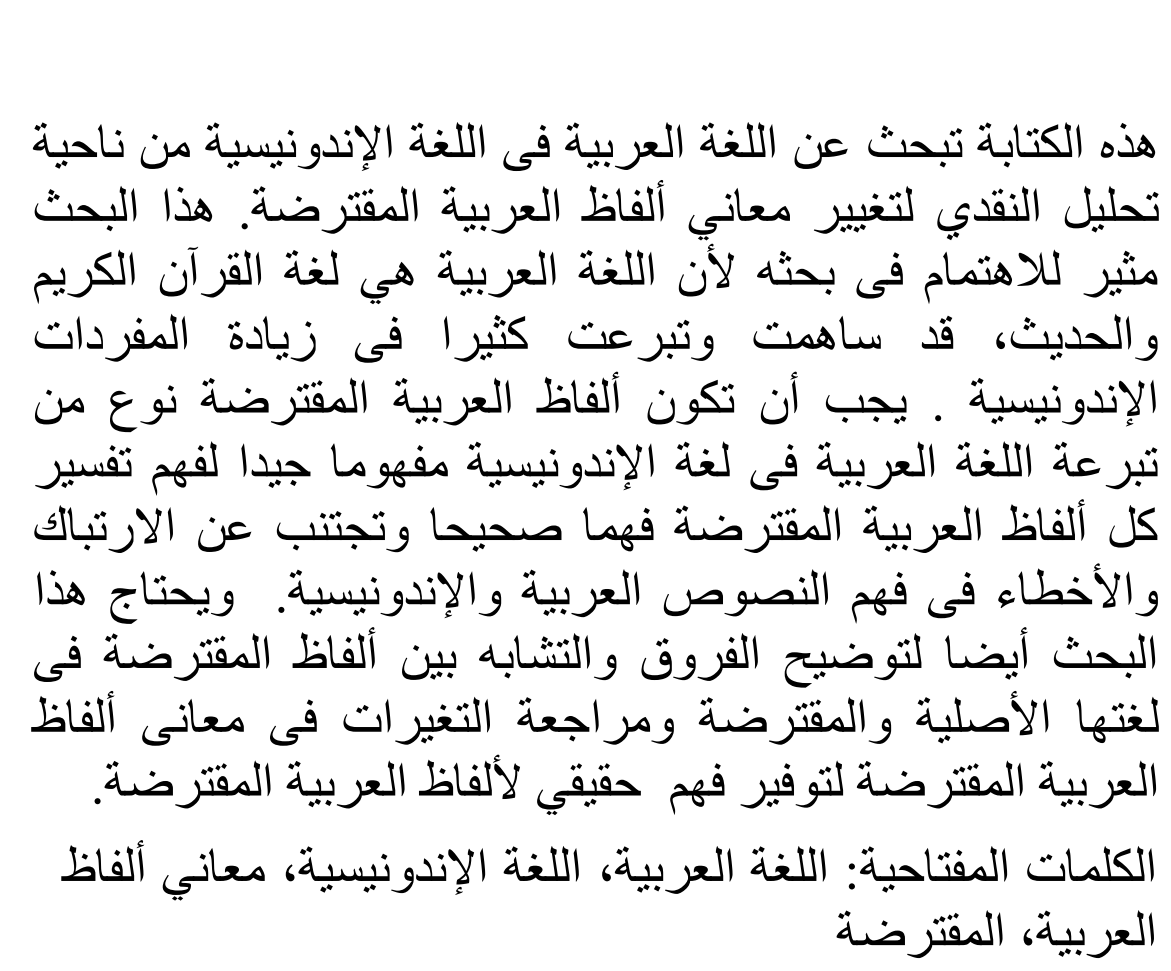

\begin{abstract}
Abstrak
Tulisan ini mengkaji tentang bahasa Arab dalam bahasa Indonesia, suatu analisis kritis terhadap perubahan makna kata serapan bahasa Arab. Sub masalah dalam tulisan ini yaitu bagaimana perubahan makna kata serapan bahasa Arab dan bagaimana penyimpangan perubahan makna kata serapan bahasa Arab dalm bahasa Indonesia. Kajian ini menarik untuk dibahas mengingat bahasa Arab sebagai bahasa kitab suci al-Qur'an dan hadis telah ikut andil dan berkontribusi dalam menambah khazanah perbendaharaan kata bahasa Indonesia. Kata serapan Arab sebagai salah satu bentuk kontribusi bahasa Arab bagi bahasa Indonesia perlu dipahami dengan baik, sehingga berimplikasi pada pemahaman yang baik terhadap penginterpretasian setiap kata
\end{abstract}


serapan bahasa Arab, serta menghindari kerancuan dan kesalahan dalam memahami teks-teks berbahasa Arab maupun berbahasa Indonesia. Pengkajian tersebut juga diperlukan untuk memperjelas titik perbedaan dan persamaan makna kata serapan pada bahasa sumber dan bahasa penyerap, serta peninjauan kembali terhadap perubahan makna kata serapan bahasa Arab untuk memberikan pemahaman yang sesungguhnya terhadap kata serapan bahasa Arab.

Kata kunci: Bahasa Arab, bahasa Indonesia, makna lafadz.

\section{A. Pendahuluan}

Kata serapan merupakan bagian dari bentuk perkembangan dan ciri keuniversalan suatu bahasa. Menurut Abdul Gaffar Ruskhan, pengaruh bahasa lain ke dalam bahasa tertentu terlihat pada kosakata yang dipungut oleh bahasa tersebut dan hal itu merupakan ciri keuniversalan bahasa, tidak ada bahasa yang tidak luput dari pengaruh bahasa atau dialek lain. ${ }^{1}$

Bahasa yang hidup adalah bahasa yang terus mengalami perkembangan dan bersifat dinamis. Kedinamisan bahasa terjadi karena bahasa merupakan hasil dari kebudayaan manusia dan bisa berubah untuk mengekspresikan tujuan pribadi atau kelompok. ${ }^{2}$ Oleh karena itu, bahasa akan terus berkembang seiring dengan perkembangan kehidupan dan kebutuhan manusia sebagai penutur bahasa.

Bahasa dan kehidupan manusia diibaratkan sebuah koin, salah satu sisinya adalah bahasa dan sisi lainnya adalah manusia. Hal tersebut tidak terlepas dari fungsi bahasa yang begitu urgen dalam kehidupan manusia, baik sebagai sarana untuk berpikir, mendeskripsikan ide, alat untuk berekspresi, media penghubung antar kelompok, alat politik, dan sebagainya. ${ }^{3}$

Bahasa yang statis, kaku dan stagnan akan terkuras bahkan punah oleh zaman, jika tidak bersifat dinamis dan berkembangan. Kedinamisan dan perkembangan suatu bahasa merupakan suatu keniscayaan untuk bisa survive dan eksis dalam dunia kehidupan.

Menurut 'Ali 'Abd al-Wahijd Wafi>perkembangan sebuah bahasa dipengaruhi oleh beberapa faktor, diantaranya adanya pengaruh bahasa lain serta faktor sosialgeografis, seperti budaya, adat istiadat dan keyakinan masyarakat. ${ }^{4}$

Bahasa Indonesia memiliki sifat yang dinamis dan tidak tertutup akan masuknya berbagai unsur kebahasaan asing di dalamnya. Integrasi bahasa Indonesia

${ }^{1}$ Abdul Gaffar Ruskhan, Pungutan Padu Bahasa Arab dalam Bahasa Indonesia (Cet. 1; Jakarta: PPPB, 2000), h. 1.

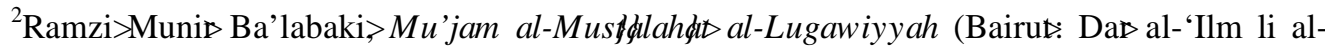
Malayin, 1990), h. 272.

${ }^{3}$ Acep Hermawan, Metodologi Pembelajaran Bahasa Arab (Bandung: PT Remaja Rosda Karya, 2014), h. 24.

4'Ali ‘Abd al-Wahiłd Wafił 'Ilm al-Lugah (Misıł: Maktabah Nahdł̧h, 1962), h. 226. 
dengan bahasa lain menyebabkan bahasa Indonesia dengan mudah menyerap berbagai unsur bahasa asing, khususnya kosakata. Bahasa Indonesia telah menyerap kosakata asing dari berbagai bahasa pemberi pengaruh seperti; bahasa Sansekerta, Inggris, Arab, Belanda, Portugis dan lain-lain.

Salah satu bahasa asing pendonor kosakata dalam bahasa Indonesia di atas yaitu bahasa Arab. Bahasa Arab mempunyai pengaruh dan integrasi yang kuat dengan bahasa Indonesia, ikatan keagamaan yang dianut oleh mayoritas penduduk Indonesia menjadi salah satu penyebab kuat dan signifikannya pengaruh bahasa Arab di dalamnya. Bahasa Arab turut berkontribusi dalam mengembangkan dan memperkaya khazanah perbendaharaan kata bahasa Indonesia dalam berbagai bidang kebahasaan, seperti pada bidang sosial, hukum dan ketatanegaraan, pendidikan, ilmu pengetahuan, dan terutama pada bidang keagamaan. Sadar atau tidak sadar kata serapan bahasa Arab menjadi salah satu kata serapan yang lazim digunakan oleh masyarakat Indonesia sebagai sarana komunikasi hariannya dalam berbagai lini kehidupan.

Secara historis, proses penyerapan kata asing -khususnya kata serapan bahasa Arab- berlangsung secara audial (pendengaran), artinya pengambilan kata tersebut melalui indra pendengaran, atau peniruan sesuai dengan apa yang didengar dari native speaker. Karena sebagian sistem fonologi bahasa Arab berbeda dengan sistem fonologi bahasa Indonesia, maka bunyi ujaran tersebut ditiru menurut kemampuan lidah melafalkannya, sehingga akan ditemukan perbedaan yang signifikan pada sebagian bunyi kata serapan tersebut. Selain permasalahan fonologi, permasalahan lain yang muncul pada penyerapan kata bahasa Arab dalam bahasa Indonesia yaitu permasalahan semantik.

Istilah semantik dalam bahasa Arab dikenal dengan sebutan 'ilm al-ma'na> atau al-dilabah. ${ }^{5}$ Ali al-Khuli mendefinisikan al-ma'na atau al-dilabah sebagai berikut;

Maksudnya:

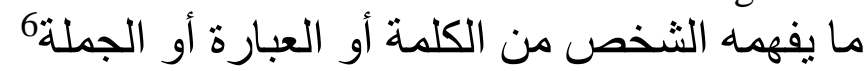

Al-ma'na atau al-dilabah adalah sesuatu yang dipahami seseorang, apakah itu berupa kata, ungkapan maupun kalimat.

Manqu» 'Abd al-Jali» menjelaskan istilah al-dilabah dengan al-ma'na> merupakan dua istilah yang berbeda. Istilah al-dilabah bersifat umum, tidak hanya digunakan dalam simbol bahasa saja, akan tetapi digunakan di luar simbol bahasa juga, sedangkan istilah al-ma'na>lebih bersifat khusus, hanya digunakan dalam symbol bahasa dan istilah tersebut lebih populer dikenal dalam bidang balagah yaitu 'ilm al-ma'ari?'

Definisi-definisi tersebut menunjukkan bahwa semantik merupakan salah satu kajian dalam bidang linguistik yang memfokuskan analisis dan kajiannya pada makna atau arti suatu bahasa.

${ }^{5}$ Manqu» 'Abd al-Jalil, 'Ilm al-Dilabah: Ushluhu wa Mabatiskhu fi al-Turast al-'A rabi> (Dimasyq: Mansyurat Ittihłd al-Kitab al-'Arabi>2001), h.13.

${ }^{6}$ Muhammad Ali al-Khuli, A Dictionary Of Theoretical Linguistics (Lebanon: Lebraire Du Liban, 1982), h. 166.

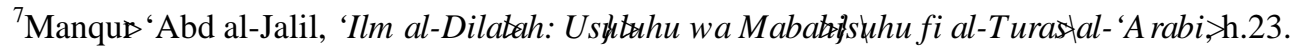


Fenomena kata serapan pada aspek semantik melahirkan keambiguan, yang mengarah pada kekeliruan bahkan kesalahan dalam memahami dan menginterpretasikannya. Sebagian masyarakat mengalami kebingungan dalam memahami dan membedakan makna dari kata serapan yang memiliki kedekatan pelafalan. Misalnya makna kata mahram dan muhrim yang diserap dari kata مَحْرَم dan مُحْرم Ada yang mengatakan bahwa mahram lebih tepat untuk menunjukkan makna orang yang haram dinikahi karena sebab tertentu daripada kata muhrim, ada pula yang memahami bahwa kata muhrim lah yang lebih tepat untuk pemaknaan tersebut.

Kata serapan bahasa Arab pada beberapa literatur berbahasa Arab juga terkadang dialihbahasakan atau diterjemahkan ke dalam bahasa Indonesia begitu saja tanpa melihat konteks kalimat pada bahasa sumbernya yang melahirkan beragam makna, sehingga dipahami sebagaimana pemahaman pada bahasa penyerap bukan sebagaimana pada bahasa sumbernya. Misalnya kata fitnah pada QS Al-Baqarah/2: 193 dan QS Ak' 'Imran/3: 7 pada al-Qur'an dan Terjemahan Kementerian Agama diterjemahkan apa adanya dengan kata fitnah itu sendiri. Padahal jika dilihat konteks kalimat pada kedua ayat tersebut dan dibandingkan dengan makna kata fitnah pada kamus besar bahasa Indonesia yang menjadi rujukan yang handal dalam memahami sebuah kata dalam bahasa Indonesia, maka kata fitnah pada kedua ayat tersebut tidak tepat diterjemahkan dengan kata fitnah itu sendiri. Pada kamus besar bahasa Indonesia kata fitnah bermakna; perkataan bohong atau tanpa berdasarkan kebenaran yang disebarkan dengan maksud menjelekkan orang. ${ }^{8}$

Diperlukan suatu kajian tentang kata serapan bahasa Arab dalam bahasa Indonesia untuk dapat menghindari kesimpangsiuran dan kesalahan dalam menginterpretasi makna kata serapan bahasa Arab yang telah menjadi kata baku dalam bahasa Indonesia. Pengkajian tersebut diperlukan untuk menjelaskan titik persamaan dan perbedaan makna kata serapan baik pada bahasa sumber maupun bahasa penyerap. Selain itu kritikan diperlukan untuk meninjau kembali perubahan makna kata serapan bahasa Arab untuk memberikan pemahaman yang sesungguhnya pada kata serapan, apalagi jika kata serapan tersebut berkaitan dengan masalah akidah umat yang beragama.

Pemahaman yang baik terhadap kata serapan, baik pada bahasa sumber maupun bahasa penyerap akan menambah khazanah sekaligus wawasan pengetahuan terhadap kedua bahasa tersebut, terlebih lagi bahasa Arab sebagai salah satu bahasa utama di dunia dan menjadi bahasa kitab suci umat Islam (al-Qur'an), hadis dan kitab-kitab klasik yang menjadi rujukan utama dalam memahami ajaran Islam.

\section{B. Kata Serapan Bahasa Arab dalam Bahasa Indonesia}

Kata serapan didefiniskan oleh para ahli bahasa dengan berbagai definisi. Definisi-definisi yang dikemukakan sesungguhnya saling berkaitan dan memperjelas hakikat dari kata serapan itu sendiri. Misalnya Haugen dalam Junanah menjelaskan bahwa kata serapan adalah reproduksi yang diupayakan dalam suatu bahasa mengenai pola-pola yang sebelumnya ditemukan dalam bahasa lain. ${ }^{9}$ Heah Lee Hsia

${ }^{8}$ Departemen Pendidikan Nasional, Kamus Besar Bahasa Indonesia, Edisi IV (Cet. I; Jakarta: Pusat Bahasa Departemen Pendidikan Nasional, 2008), h. 393.

${ }^{9}$ Junanah, Kata Serapan Bahasa Arab dalam Serat Centhini: Kajian Morfosemantis (Jogjakarta: Safiria Insania Press, 2010), h.5. 
dalam Abdul Gaffar menjelaskan bahwa pemungutan (penyerapan) adalah proses pengambilan dan penggunaan unsur bahasa lain dalam konteks lain. ${ }^{1}$

Definisi-definisi yang dikemukakan oleh kedua ahli bahasa di atas bermuara pada proses pengambilan pola-pola atau unsur-unsur bahasa asing kemudian digunakan pada bahasa tertentu dengan penyesuaian kaidah dalam bahasa penyerap. Dengan demikian kata serapan bahasa Arab adalah semua yang masuk ke dalam bahasa Indonesia berupa kosakata yang bersumber atau berasal dari bahasa Arab dan direproduksi dengan penyesuaian kaidah bahasa Indonesia kemudian menjadi bagian dari bahasa tersebut.

Bahasa Arab mengenal istilah kata serapan dengan istilah ta'rib dan dakhis. Kedua istilah tersebut muncul sebagai bentuk respon dari lembaga-lembaga bahasa Arab terhadap perkembangan dan kedinamisan bahasa Arab sebagai salah satu bahasa utama di dunia.

Kata al-dakhi $\triangleright$ berakar dari kata yang berarti masuk, sehingga al-dakhi॰ berarti pemasukan atau sisipan. Secara terminologi, al-dakhiচberarti setiap kata yang dimasukkan atau disisipkan dalam pembicaraan orang-orang Arab tetapi bukan bagian dari bahasa mereka. ${ }^{11}$ Sedangkan kata al-ta'rib adalah bentuk infinitif dari verba yang bermakna pengaraban atau arabisasi. Sedangkan secara terminologi al-ta'rib bermakna penyerapan unsur-unsur asing, baik berupa kata maupun istilah.

Perbedaan dari kedua istilah di atas yaitu dalam al-ta'rib kata-kata yang diserap mengalami perubahan sesuai dengan kaidah bahasa Arab yang baku, sedangkan dalam al-dakhi॰ tidak mengalami transformasi dan digunakan sebagaimana bentuk aslinya. Istilah al-dakhiblebih umum dan luas bila dibandingkan dengan istilah al-ta'rib.

Penentuan unsur maupun kata serapan bahasa Arab harus ditentukan dengan kriteria-kriteria tertentu sehingga terhindar dari kesalahan maupun kekeliruan dalam penentuannya. Menurut Nyoman ada tiga kriteria yang diajukan oleh ahli bahasa sebagai patokan dalam menentukkan apakah sebuah kata berasal dari bahasa asing atau kata asli dalam bahasa Indonesia. Ketiga kriteria tersebut yaitu; 1) kemiripan lafal, 2) keeratan kontak, dan 3) pendapat para ahli bahasa.

Penentuan kata serapan bahasa Arab setidak-tidaknya harus memenuhi ketiga kriteria di atas, setelah itu baru bisa dilakukan penganalisisan terhadap perubahan makna yang ditimbulkan setelah melalui tahap penyerapan. Kemiripan lafal menjadi petunjuk awal dalam penentuan apakah kata tersebut sebagai kata asing atau unsur asli pada bahasa Indonesia, tetapi itu bukanlah jaminan tunggal dalam penentuannya, misalnya kata makan memiliki kemiripan lafal dengan kata (makarun) pada bahasa Arab, tetapi ahli bahasa tidak menyebutnya sebagai kata serapan bahasa Arab. Pendapat ahli bahasa bisa ditemukan pada berbagai sumber literatur-literatur

\footnotetext{
${ }^{10}$ Abdul Gaffar Ruskhan, Bahasa A rab dalam Bahasa Indonesia (Jakarta: Gramedia Pustaka Utama, 2008), h.100.

${ }^{11}$ Louis Ma'luf, al-Munjid fi al-Lugah wa al-A laæn (Bairut. Da» al-Masyriq, 2005), h.495.

${ }^{12}$ Syamsul Hadi, "Berbagai Ketentuan Baru dalam Ta'rib", Humaniora XIV, no.1 (2002), h.77.

${ }^{13}$ Nyoman Tusthi Eddyy, Unsur Serapan Bahasa A sing dalam Bahasa Indonesia (Ende Flores: Nusa Indah, 1989), h.23.
} 
yang ada, baik berupa buku maupun kamus yang merupakan pendapat dari para penyusunnya.

\section{Perubahan Makna Kata Serapan Bahasa Arab}

Transformasi makna kata serapan bahasa Arab perlu dipahami dengan baik untuk menghindari ambiguitas, kekeliruan dan kesalahan dalam menginterpretasi sebuah kata serapan baik dalam bahasa verba (komunikasi) maupun bahasa nonverbal (tulisan) yang menjadi konsumsi harian bagi pengguna bahasa.

Transformasi makna kata serapan menurut Abdul Chaer ada 3 yaitu perubahan makna meluas, menyempit dan perubahan makna total. Suatu kata dikatakan meluas maknanya apabila makna yang baru lebih luas dari makna terdahulu. Perubahan makna menyempit merupakan perubahan makna yang lebih khusus, terperinci dan kecil dari makna sebelumnya. Apabila perubahan-perubahan tersebut tidak menyisakan makna, maka dikatakan sebagai perubahan makna total. ${ }^{14}$

Dengan kata lain, makna meluas yaitu makna baru yang diproduksi oleh bahasa penyerap mengalami perkembangan, penambahan atau perluasan makna yang tidak ditemukan pada bahasa sumber. Makna menyempit yaitu makna baru yang diproduksi oleh bahasa penyerap mengalami spesifikasi atau penyempitan bila dibandingkan dengan bahasa sumbernya. Adapun perubahan makna total yaitu makna yang diproduksi oleh bahasa penyerap tidak menunjukkan adanya korelasi atau relevansi dengan makna dari bahasa sumbernya.

Perubahan makna total tidak ditemukan pada data yang telah dikaji. Semua kata serapan bahasa Arab memiliki relevansi dan korelasi dengan makna bahasa sumbernya. Relevansi makna-makna tersebut bisa diungkap dengan menggunakan analisis padan intralingual (menghubung-bandingkan) yaitu metode analisis dengan cara menghubung-bandingkan unsur-unsur yang bersifat lingual, baik yang terdapat pada suatu bahasa maupun beberapa bahasa yang berbeda. Dan dengan menggunakan tekhnik analisis hubung banding menyamakan dan tekhnik hubung banding membedakan, yang bertujuan menemukan kesamaan pokok dan perbedaan pokok dari apa yang dibandingkan.

Perubahan makna total akan ditemukan pada makna kata serapan bahasa Arab jika hanya dilihat pada satu sisi perubahan makna, tetapi jika dilihat disudut yang lain maka akan ditemukan korelasi maupun relevansi makna kata pada bahasa sumber maupun bahasa penyerap. Misalnya kata jahil dan sejarah (yang diserap dari kata جَاهِ pَجَرَة dan pada artikel Tadkiroatun Musfiroh ${ }^{15}$ dikategorikan sebagai perubahan makna total. Jika dianalisis secara objektif maka kata jahil dan sejarah memiliki makna yang relevan dan korelatif dengan makna pada bahasa sumbernya. Kata jahil memang mengalami perkembangan makna menjadi jail (suka mengganggu orang lain, nakal), tetapi jahil juga mengandung makna bodoh, tidak tahu. Sehingga perubahan makna kata jahil dikategorikan sebagai perubahan makna meluas bukan perubahan makna total.

\footnotetext{
${ }^{14}$ Abdul Chaer, Linguistik Umum (Jakarta: Rineka Cipta, 2007), h.313.

${ }^{15}$ Tadkiroatun Musfiroh, "Perbedaan Makna Kata-Kata Bahasa Indonesia Serapan Bahasa Arab dari Makna Sumbernya”, Diksi 11, no. 1 (2004).

${ }^{16}$ Departemen Pendidikan Nasional, Kamus Besar Bahasa Indonesia, Edisi IV, h. 557.
} 
Hal yang sama juga pada makna kata sejarah yang dikategorikan sebagai perubahan makna total. Padahal dalam bahasa Indonesia kata sejarah juga bermakna; asal-usul (keturunan) silsilah, bukan sekedar kejadian dan peristiwa yang benar-benar terjadi pada masa lampau. Makna silsilah pada bahasa penyerap ditemukan juga pada makna syajarah di bahasa sumber, sehingga perubahan makna pada kata tersebut seharusnya disebut sebagai perubahan makna meluas bukan perubahan makna total.

\section{Makna Meluas}

Perkembangan, penambahan atau perluasan makna yang diproduksi oleh bahasa penyerap dan tidak terdapat pada makna bahasa sumbernya disebut sebagai perluasan makna. Berdasarkan data ditemukan sejumlah kata serapan bahasa Arab yang mengalami perluasan makna seperti kata abdi, ayat, dunia, jahannam dan maut.

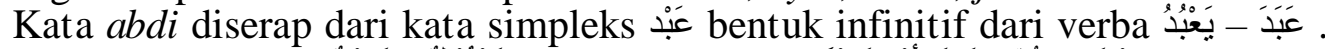

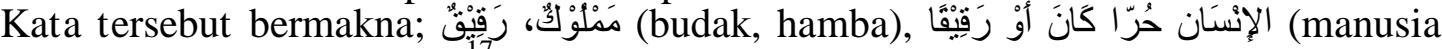
yang merdeka atau budak). ${ }^{17}$ Kata 'abdun kemudian diserap menjadi kata abdi yang bermakna; orang bawahan, pelayan, hamba, dan budak tebusan. ${ }^{18}$

Sekilas makna kedua kata tersebut terlihat sama, tetapi realitasnya terjadi perkembangan makna pada bahasa penyerap. Perkembangan makna tersebut dapat dipahami pada penggunaan kata abdi dalam kalimat, misalnya; Tentara adalah abdi Negara. Kata abdi pada kalimat tersebut bermakna; pegawai atau orang yang berkerja pada pemerintahan atau pegawai negeri. Makna tambahan tersebut berbeda dengan makna 'abdun pada bahasa sumber, dan untuk menunjukkan makna 'pegawai'

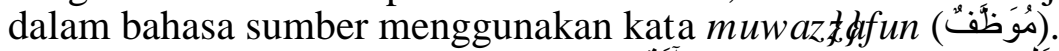

Kata ayat diserap dari kata آَيَة مِنْ الثُرْآن : جُمْلَة أو جُمَل (kalimat atau beberapa kalimat dalam al-Qur'an), selain itu kata $a y a h$ juga bermakna;

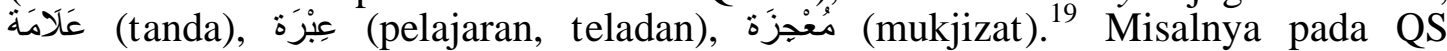
Fus\$illat/41: 53, QS Yunus/10: 92 dan QS al-Mu'minun/23: 50). Kata $a y a h$ kemudian diserap ke dalam bahasa Indonesia menjadi ayat, dan mengalami perkembangan makna berupa 'beberapa kalimat yang merupakan kesatuan maksud bagian pasal dalam undang-undang'.

Perkembangan makna juga terjadi pada kata dunia, jahannam dan maut. Kata

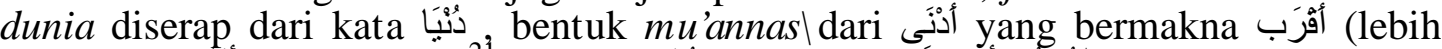

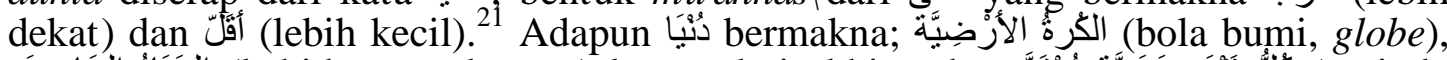

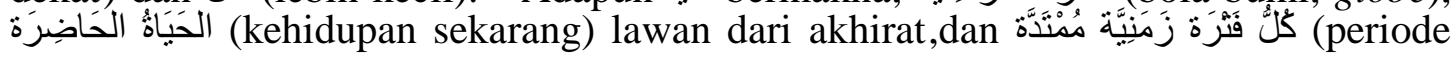

${ }^{17}$ Al-Munazłłmah al- 'Arabiyyah li al-Tarbiyyah wa al-Słqafah wa al-'Ulum, al-Mu’jam al'A rabi al-A sasi †t.t. : t.p., t..th.), h. 815.

${ }^{18}$ Departemen Pendidikan Nasional, Kamus Besar Bahasa Indonesia, Edisi IV, h. 2.

${ }^{19}$ Al-Munazłąmah al-'Arabiyyah li al-Tarbiyyah wa al-Słqafah wa al-'Ulum, al-Mu’jam al'A rabi al-A sasi, h. 124.

${ }^{20}$ Departemen Pendidikan Nasional, Kamus Besar Bahasa Indonesia, Edisi IV, h. 106.

${ }^{21}$ Ahmad Warson Munawwir, al-Munawwir Qałı 'A rabi>- Induæisi>(Cet. IV; Surabaya: Pustaka Progressif, 1997), h. 426. 


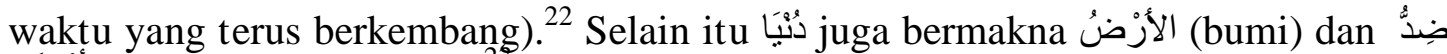
الأفْصَى (lawan dari jauh). ${ }^{23}$ Dalam bahasa Indonesia kata dunia mengalami perkembangan makna dan digunakan dalam berbagai istilah lain, seperti; piala dunia, dunia internasional, dunia hiburan, dunia pendidikan dan sebagainya. Penggunaan kata dunia pada frase tersebut berbeda dengan bahasa sumber, dalam bahasa Arab

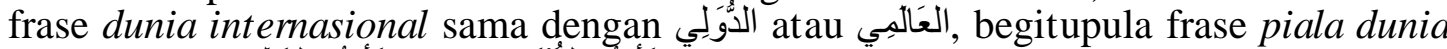

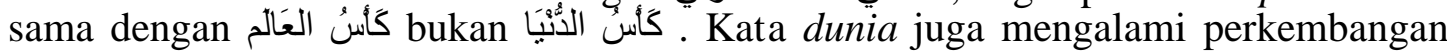
makna (pembicaraan perkawinan di Halmahera) yang tidak dipahami pada bahasa sumber.

Kata jahannam dalam bahasa Indonesia lazim digunakan untuk mengumpat orang lain, seperti pada kalimat; perempuan jahannam, enyah dari sini. ${ }^{24}$ Jahannam pada kalimat tersebut bermakna; terkutuk atau jahat sekali. Penggunaan kata jahannam sebagai bentuk umpatan dan caci maki seperti pada kalimat tersebut tidak terdapat pada bahasa sumbernya. Hal demikian menunjukkan bahwa kata jahannam setelah diserap dalam bahasa Indonesia mengalami perluasan makna.

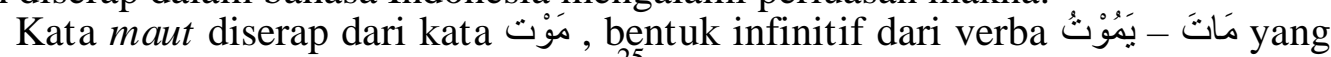
bermakna; mati, menjadi tenang, mereda. ${ }^{25}$ Adapun bentuk infinitifnya bermakna; kematian dan الخَوْنَ وَالحُرْْن (ketakutan dan kesedihan). ${ }^{26}$ Kata maut diserap ke dalam bahasa Indonesia dengan makna yang sama (kematian) dan mengalami perkembangan makna, berupa; mengagumkan, hebat dan luar biasa. ${ }^{27}$ Misalnya pada frase; tendangan maut dan goyang maut. Kata maut pada kedua frase tersebut tidak menunjukkan makna hakikinya berupa kematian, melainkan bermakna kekaguman dan kehebatan dari tindakan yang dilakukan. Makna demikian tidaklah diterima dalam bahasa sumber, karena untuk menunjukkan makna kekaguman atau sesuatu

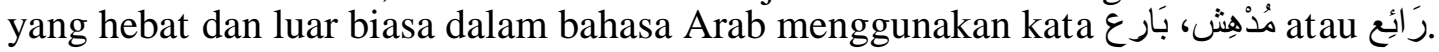

\section{Makna Menyempit}

Penyempitan makna yaitu makna baru yang diproduksi dalam bahasa penyerap mengalami spesifikasi atau penyempitan bila dibandingkan dengan bahasa sumbernya. Berdasarkan data ditemukan sejumlah kata serapan bahasa Arab yang mengalami penyempitan makna seperti kata alim, aurat, dai, hafiz/hufaz, jamaah, dakwah dan maulid.

Kata alim diserap dari kata عَالِ yang bermakna; mengetahui, mengenali, menemukan dan sebagainya.

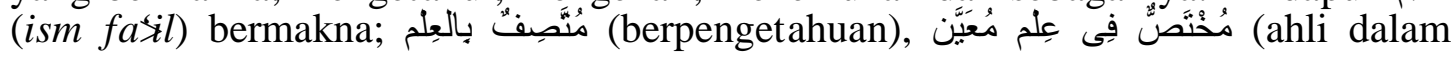

${ }^{22}$ Al-Munazłamah al-'Arabiyyah li al-Tarbiyyah wa al-Słqafah wa al-'Ulum, al-Mu’jam al'A rabial-A sasi, h. 465.

${ }^{23}$ Ahmad Warson Munawwir, al-Munawwir Qaæu us 'A rabi> Induðisi, h. 426.

${ }^{24}$ Departemen Pendidikan Nasional, Kamus Besar Bahasa Indonesia, Edisi IV, h. 556.

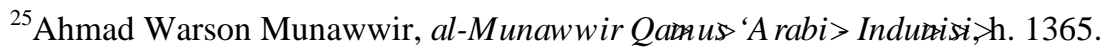

${ }^{26}$ Al-Munazłąmah al-'Arabiyyah li al-Tarbiyyah wa al-Słqafah wa al-'Ulum, al-Mu’jam al'A rabi al-A sasi, h. 1159.

${ }^{27}$ Departemen Pendidikan Nasional, Kamus Besar Bahasa Indonesia, Edisi IV, h. 890.

${ }^{28}$ Ahmad Warson Munawwir, al-Munawwir Qaæu us 'A rabi> Induæisi, h. 966. 
bidang tertentu). ${ }^{29}$ Setelah diserap ke dalam bahasa Indonesia kata alim mengalami perkembangan makna; saleh dan pegawai urusan agama di Banten dan Madura. ${ }^{30}$ Meskipun demikian, kata alim dikategorikan mengalami penyempitan makna karena selain kedua makna diatas, kata alim juga bermakna; berilmu terutama dalam hal agama Islam. Penspesifikasian makna alim yang dibatasi pada pengetahuan dalam urusan agama Islam, jelas berbeda dengan makna 'alim pada bahasa sumber yang bersifat 'am atau general (berpengetahuan umum maupun keagamaan).

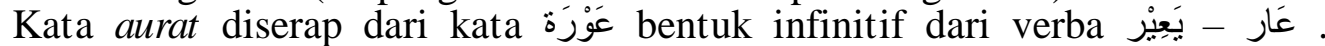
Setelah diserap dalam bahasa Indonesia kata aurat mengalami penspesifikasian makna yaitu; kemaluan atau organ-organ untuk mengadakan perkembangbiakan. Makna tersebut menyempit dari makna pada bahasa sumbernya, hal tersebut tidak terlepas dari realitas sosial masyarakat Indonesia yang multi kultural dan masyarakatnya yang heterogen.

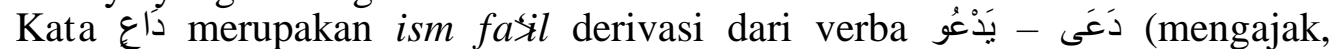
mengundang). Bentuk ism fa il tersebut bermakna; pengajak, penyeru, pengundang. Kata da in kemudian diserap ke dalam bahasa Indonesia menjadi kata dai yang bermakna; orang yang kerjanya berdakwah atau pendakwah. ${ }^{31}$ Makna dai pada bahasa penyerap menunjukkan adanya penyempitan atau penspesifikasian makna. Da in pada bahasa sumber bersifat 'am (umum) tidak dibatasi pada pendakwah yang

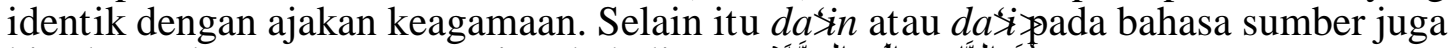
bisa bermakna muazin seperti pada kalimat; هوَ الدَّابِى إلَى الصَّلَاة .

Penghafal al-Qur'an dalam bahasa Indonesia disebut sebagai hafiz atau

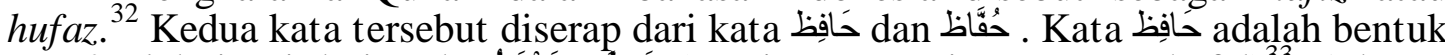

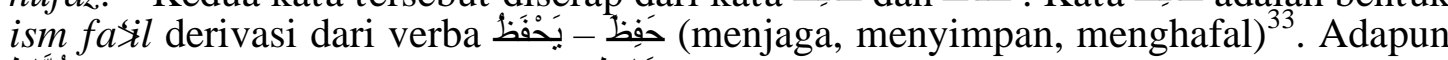
حقَّاظ حَفَظ adalah bentuk plural dari bermakna; penjaga, penyimpan, dan

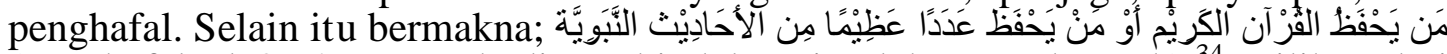
(penghafal al-Qur'an atau hadis Nabi dalam jumlah yang banyak). ${ }^{34}$ Dilihat dari makna $h \dot{\phi} f \dot{f} z\}$ dan hhffaz\} pada bahasa sumber, maka kata hafiz dan hufaz dalam bahasa Indonesia mengalami penyempitan atau penspesifikasian makna. Dalam bahasa Arab, penghafal al-Qur'an disebut juga dengan حَامِلُ القُرْْان tidak terbatas pada saja.

Kata جَاعَة (jamaðh) bermakna; kelompok orang atau kawanan binatang. ${ }^{35}$ Kata tersebut diserap menjadi kata jemaah dan jemaat. Kata jemaah bermakna;

${ }^{29} \mathrm{Al}$-Munazłłmah al-‘Arabiyyah li al-Tarbiyyah wa al-Sqqafah wa al-'Ulum, al-Mu’jam al'A rabial-A sasi, ‘h. 861.

${ }^{30}$ Departemen Pendidikan Nasional, Kamus Besar Bahasa Indonesia, Edisi IV, h. 41.

${ }^{31}$ Departemen Pendidikan Nasional, Kamus Besar Bahasa Indonesia, Edisi IV, h. 287.

${ }^{32}$ Departemen Pendidikan Nasional, Kamus Besar Bahasa Indonesia, Edisi IV, h.473 dan 509.

${ }^{33} \mathrm{Ahmad}$ Warson Munawwir, al-Munawwir Qaær us 'A rabi> Induæitsi; >h. 279.

${ }^{34} \mathrm{Al}-\mathrm{Munaz}$ 好ah al- ‘Arabiyyah li al-Tarbiyyah wa al-Słqafah wa al-'Ulum, al-Mu’jam al'A rabizl-A sasi, ‘h. 333.

${ }^{35}$ Louis Ma'luf, al-Munjid fi al-Lugah wa al-A 'lam, h. 101. 
kumpulan atau rombongan orang beribadah, orang banyak dan publik. ${ }^{36}$ Pembatasan makna jemaah pada rombongan atau kumpulan orang di atas menunjukkan bahwa kata jemaah setelah diserap dalam bahasa Indonesia mengalami spesifikasi atau penyempitan makna karena dalam bahasa sumber mencakup juga kawanan binatang. Begitupula pada kata jemaat yang bermakna; sehimpunan umat. Penyempitan makna kata tersebut tidak terlepas dari lazimnya penggunaan kata jemaah pada kegiatan peribadatan, seperti jemaah haji, jemaah salat dan sebagainya.

Penyempitan makna juga terjadi pada kata dakwah yang diserap dari kata

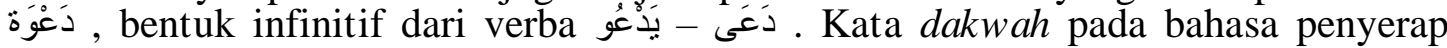
bermakna; 1) penyiaran, propaganda, 2) penyiaran agama dan pengembangannya di kalangan masyarakat, seruan untuk memeluk, mempelajari dan mengamalkan ajaran agama. ${ }^{37}$ Da'wah pada bahasa sumbernya memiliki makna yang beragama dan tidak terbatas pada propaganda maupun penyiaran dan pengembangan ajaran agama saja. Da'wah memiliki makna konotasi berupa; doa, seruan, panggilan, ajakan, undangan, permintaan dan sebagainya. ${ }^{38}$ Makna-makna tersebut akan sangat jelas ketika berada pada konteks kalimat maupun frase. Dilihat dari pemaknaan kata dakwah pada kedua bahasa tersebut, kata dakwah mengalami penyempitan makna yang terbatas pada ajakan maupun penyiaran pada bidang keagamaan, jika ajakan tersebut tidak berhubungan dengan kegiatan keagamaan maka bukanlah dinamakan sebagai dakwah. Pada bahasa sumber, makna da'wah tidak terbatas pada ajakan pada bidang keagamaan, bisa saja ajakan pada kegiatan umum lainnya.

Kata maulid diserap dari kata sَ son bentuk nomina lokatif dan temporal,

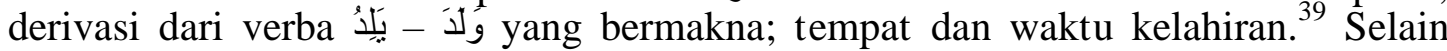
sebagai nomina lokatif dan temporal kata maulid juga bersubkategori infinitif (masylar mimi) yang bermakna kelahiran. Kata maulid kemudian diserap ke dalam bahasa Indonesia dengan makna yang sama dengan bahasa sumbernya dan mengalami penspesifikasian. Penspesifikasian makna tersebut terlihat dari perubahan maknanya yang menspesifikan makna maulid sebagai hari lahir dan peringatan kelahiran Nabi Muhammad saw.

\section{Penyimpangan Perubahan Makna Kata Serapan Bahasa Arab dalam Bahasa Indonesia}

Penyimpangan yang dimaksud yaitu kekeliruan maupun kesalahan pada penggunaan dan penginterpretasian terhadap kata serapan bahasa Arab pada bahasa sumbernya. Banyaknya kata serapan bahasa Arab dalam bahasa Indonesia berimplikasi pada kekeliruan maupun kesalahan dalam penggunaan dan pemaknaannya. Kekeliruan dan kesalahan penggunaan kata serapan bahasa Arab bisa terjadi pada bahasa verbal (komunikasi) maupun nonverbal (tulisan). Kekeliruan tersebut terus terjadi dan bersifat turun temurun sehingga menjadi kekeliruan jemaah atau menjadi sebuah kesalahan yang dianggap sebagai kebenaran.

\footnotetext{
${ }^{36}$ Departemen Pendidikan Nasional, Kamus Besar Bahasa Indonesia, Edisi IV, h.576.

${ }^{37}$ Departemen Pendidikan Nasional, Kamus Besar Bahasa Indonesia, Edisi IV, h. 288.

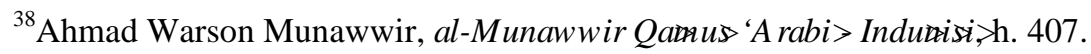

${ }^{39}$ Louis Ma'luf, al-Munjid fi al-Lugah wa al-A laær, h. 918.
} 
Kekeliruan penggunaan kata serapan bahasa Arab baik pada bahasa verbal (komunikasi) maupun nonverbal (tulisan) dianggap sebagai sesuatu yang wajar dan hal yang biasa oleh sebagian masyarakat. Tetapi kesalahan dan transformasi makna yang signifikan pada bahasa penyerap akan berimplikasi pada kekeliruan dan kesalahan dalam memahami sebagian nash-nash berbahasa Arab, baik pada alQur'an, hadis maupun teks-teks Arab lainnya yang dalam proses penerjemahan atau pemaknaannya diterjemahkan apa adanya tanpa melihat titik kesamaan maupun perbedaan pada kata serapan tersebut.

Kekeliruan dalam pemaknaan kata serapan bahasa Arab misalnya ditemukan pada pemaknaan kata fitnah dalam al-Qur'an dan terjemahan Kementerian Agama RI. Dalam KBBI kata fitnah berarti perkataan bohong atau tanpa berdasarkan kebenaran yang disebarkan dengan maksud menjelekkan orang (seperti; menodai nama baik, merugikan kehormatan orang). ${ }^{40}$

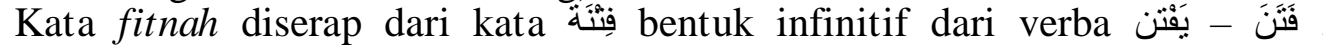
Sebagian kata fitnah pada al-Qur'an dan terjemahan Kementerian Agama RI tidak diterjemahkan sebagaimana mestinya, atau diterjemahkan apa adanya dengan kata fitnah itu sendiri. Padahal hal tersebut dapat menimbulkan kesalahpahaman dan kekeliruan apalagi bagi masyarakat yang masih awam dalam pengetahuan bahasa Arabnya. Misalnya kata fitnah dalam QS Al-Baqarah/2: 193, pada al-Qur'an dan terjemahan Kementerian Agama RI diterjemahkan dengan kata fitnah juga, begitupula pada QS Ak' 'Imran/3: 7 dan QS Al-Anfa甘8: 39. Padahal kata fitnah pada ayat-ayat tersebut memiliki makna yang beragam karena konteksnya yang berbeda. Quraish Shihab mengartikan kata fitnah pada QS Al-Baqarah/2: 193 dengan 'syirik dan penganiayaan', pada QS Ak' 'Imran/3: 7 diartikan dengan 'kekacauan dan kerancuan serta keraguan di kalangan orang beriman', ${ }^{42}$ sedangkan pada QS AlAnfał8: 39, Quraish Shihab mengartikannya dengan 'kekacauan, penindasan, penganiayaan dan syirik'. ${ }^{43}$

Kekeliruan dalam transformasi makna kata serapan juga terjadi pada kata keramat, muhrim, alkitab dan almarhum/almarhumah. Berikut adalah penjelasan dari masing-masing kata tersebut.

Kata keramat diserap dari kata كَرَامَة, bentuk infinitif dari verba كَرْمَ - يَكَرْ

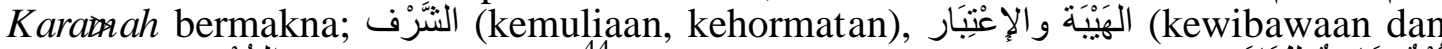

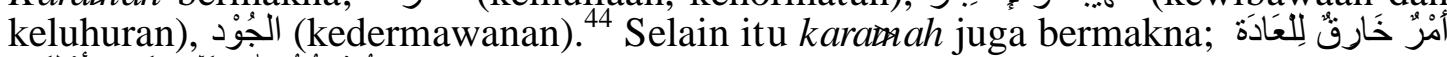

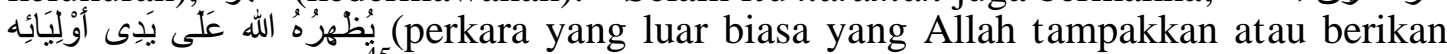
pada wali-waliNya). ${ }^{45}$ Kata karamah kemudian diserap dalam bahasa Indonesia

${ }^{40}$ Departemen Pendidikan Nasional, Kamus Besar Bahasa Indonesia, Edisi IV, h. 393.

${ }^{41}$ M. Quraish Shihab, Tafsir Al-Misbat, Pesan, Kesan dan Keserasian Al-Qur'an, vol.1 (Jakarta: Lentera Hati, 2002), h. 422.

${ }^{42}$ M. Quraish Shihab, Tafsir Al-Misbał, Pesan, Kesan dan Keserasian Al-Qur'an, vol.2, h.11.

${ }^{43}$ M. Quraish Shihab, Tafsir Al-Misbah, Pesan, Kesan dan Keserasian Al-Qur'an, vol.5, h. 441.

${ }^{44}$ Ahmad Warson Munawwir, al-Munawwir Qamus 'A rabi> Indu^isi, 1204.

${ }^{45} \mathrm{Al}-\mathrm{Munaz}$ łmah al-‘Arabiyyah li al-Tarbiyyah wa al-Słqafah wa al-'Ulum, al-Mu’jam al'A rabi al-A sasi, ‘. 1037. 
menjadi kata keramat dan mengalami perubahan makna yang signifikan. Perkembangan makna keramat pada bahasa Indonesia identik dengan sesuatu yang disakralkan, mempunyai kekuatan magis dan supranatural serta bertuah atau memiliki kesaktian dan kekuatan yang luar biasa. Perkembangan makna tersebut akhirnya berkonotasi negatif dan mempunyai nilai rasa yang tidak mengenakkan bahkan menakutkan. Hal tersebut bertentangan dengan makna bahasa sumbernya yang berkonotasi positif dan mengandung nilai rasa yang mengenakkan serta sesuatu yang mulia.

Kekeliruan transformasi makna kata serapan bahasa Arab juga terjadi pada kata muhrim. Kata muhrim yang diserap dari kata مُحْرْ memiliki makna yang sama dengan kata mahram yaitu orang yang masih ada hubungan keluarga dekat sehingga terlarang menikah dengannya. ${ }^{46}$ Jika ditelusuri pada bahasa sumbernya, penyamaan makna antara muhrim dengan mahram adalah sebuah kesalahan. Kedua kata tersebut memang memiliki hubungan dalam isytiqad tetapi bukan berarti sama-sama menunjukkan makna orang yang haram dinikahi. Kata muhtim adalah ism fa il yang

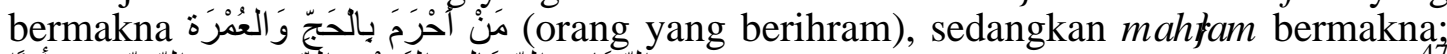

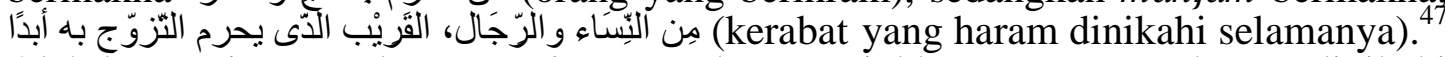
Oleh karena itu pemaknaan muhrim untuk menunjukkan orang yang haram dinikahi adalah sebuah kesalahan.

Kata alkitab dalam bahasa penyerap bermakna; 1) kitab suci agama Kristen yang terdiri atas perjanjian lama dan perjanjian baru, 2) al-Qur'an. ${ }^{48}$ Kata tersebut diserap dari kata ${ }^{2}$ yang diberi imbuhan al untuk menunjukkan kepastian objeknya. Penyerapan kata alkitab dengan makna kitab suci orang Kristen berimplikasi pada kesalahpahaman sebagian umat Islam yang masih awam dan non muslim yang beranggapan bahwa kata alkitab yang disebutkan dalam al-Qur'an (misalnya QS Al-Baqarah/1: 2) adalah kitab dari umat Kristiani, atau kata tersebut ditujukan pada kitab suci umat Kristiani dan umat Muslim (al-Qur'an) sekaligus. Kata alkitab dalam al-Qur'an juga bisa digunakan oleh orang-orang yang punya maksud dan tujuan tertentu untuk mendiskreditkan al-Qur'an yang bisa berakibat pada terjadinya disintegrasi antar umat. Penelusuran makna alkitab pada bahasa sumber juga tidaklah menunjukkan bahwa alkitab bermakna kitab suci agama Kristen, melainkan salah satu nama lain dari al-Qur'an kitab suci umat Islam. Penyebutan istilah alkitab sebagai kitab suci agama Kristen bisa diganti dengan istilah Bibel atau Injil.

Sebutan almarhum atau almarhumah ditujukan pada seorang lai-laki muslim maupun perempuan muslimah yang telah meninggal. Kedua penyebutan tersebut

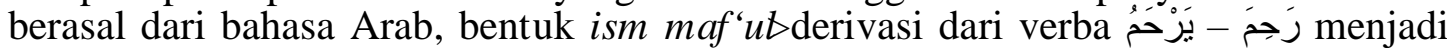
marhhımun. Untuk menunjukkan bahwa objeknya sudah pasti maka diberilah imbuhan al dan ta>marbutyh untuk menunjukkan bentuk mu'annas. Penyebutan almarhum atau almarhumah bagi orang yang sudah meninggal adalah bentuk doa dengan harapan semoga dia dirahmati oleh Allah swt, dan bukan kepastian bahwa

\footnotetext{
${ }^{46}$ Departemen Pendidikan Nasional, Kamus Besar Bahasa Indonesia, Edisi IV, h. 934.

${ }^{47}$ Al-Munazłamah al-'Arabiyyah li al-Tarbiyyah wa al-Słqafah wa al-'Ulum, al-Mu'jam al'A rabial-A sasi, h. 311.

${ }^{48}$ Departemen Pendidikan Nasional, Kamus Besar Bahasa Indonesia, Edisi IV, h. 42.
} 
orang tersebut betul-betul dirahmati atau diampuni oleh Allah sebagaimana makna tekstual dari lafal tersebut. Kekeliruan lain dari penggunaan kata almarhum atau almarhumah yaitu lafal tersebut juga digunakan untuk orang non muslim (kafir) yang telah meninggal dunia. Padahal hal tersebut jelas bertentangan dengan akidah umat Islam, tetapi karena ketidaktahuan umat terhadap makna hakiki dari lafal tersebut menyebabkan kekeliruan tersebut terus terjadi. Penyebutan yang lebih tepat untuk mayat non muslim yaitu kata atau lafal mendiang bukan almarhum maupun almarhumah bentuk doa seorang muslim kepada saudaranya sesama muslim.

\section{E. Kesimpulan} yaitu:

Berdasarkan uraian penjelasan di atas, maka dapat disimpulkan beberapa hal,

a. Perubahan makna kata serapan bahasa Arab mencakup perubahan makna meluas yaitu adanya perkembangan makna pada bahasa penyerap dan makna menyempit atau penspesifikasian makna dari bahasa sumbernya.

b. Perubahan makna kata serapan yang signifikan berimplikasi pada terjadinya penyimpangan pada perubahan makna kata serapan bahasa Arab atau kekeliruan dan kesalahan dalam penggunaan dan pemaknaannya. Sehingga diperlukan peninjauan kembali terhadap perubahan sebagian makna kata serapan yang berimplikasi pada terjadinya kesalahan dalam memahami esensi atau hakikat makna dari kata tersebut. 


\section{DAFTAR PUSTAKA}

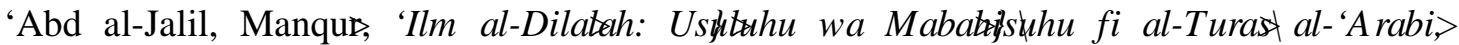
Dimasyq: Mansyurat Ittihł̆d al-Kitab al-'Arabi>2001.

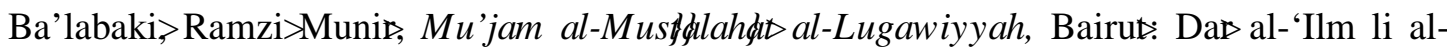
Malayin, 1990.

Chaer, Abdul, Linguistik Umum, Jakarta: Rineka Cipta, 2007.

Departemen Pendidikan Nasional, Kamus Besar Bahasa Indonesia, Edisi IV, Cet. I; Jakarta: Pusat Bahasa Departemen Pendidikan Nasional, 2008.

Eddyy, Nyoman Tusthi, Unsur Serapan Bahasa A sing dalam Bahasa Indonesia, Ende Flores: Nusa Indah, 1989.

Hadi, Syamsul, "Berbagai Ketentuan Baru dalam Ta'rib", Humaniora XIV, no.1 (2002).

Hermawan, Acep, Metodologi Pembelajaran Bahasa Arab, Bandung: PT Remaja Rosda Karya, 2014.

Junanah, Kata Serapan Bahasa Arab dalam Serat Centhini: Kajian Morfosemantis, Jogjakarta: Safiria Insania Press, 2010.

al-Khuli, Muhammad Ali, A Dictionary Of Theoretical Linguistics, Lebanon: Lebraire Du Liban, 1982.

Ma'luf, Louis, al-Munjid fi al-Lugah wa al-A lam, Bairut. Dapal-Masyriq, 2005.

Munawwir, Ahmad Warson, al-Munawwir Qamu» 'A rabi>- Induґisi> Cet. IV; Surabaya: Pustaka Progressif, 1997.

al-Munazłamah al-'Arabiyyah li al-Tarbiyyah wa al-Shqafah wa al-'Ulum, al-Mu'jam al'A rabial-A sasi, t.t. : t.p., t..th.

Musfiroh, Tadkiroatun, "Perbedaan Makna Kata-Kata Bahasa Indonesia Serapan Bahasa Arab dari Makna Sumbernya", Diksi 11, no. 1 (2004).

Ruskhan, Abdul Gaffar, Pungutan Padu Bahasa Arab dalam Bahasa Indonesia, Cet. 1; Jakarta: PPPB, 2000.

Ruskhan, Abdul Gaffar, Bahasa Arab dalam Bahasa Indonesia, Jakarta: Gramedia Pustaka Utama, 2008.

Shihab, M. Quraish, Tafsir Al-Misbah, Pesan, Kesan dan Keserasian Al-Qur'an, Vol.1, Jakarta: Lentera Hati, 2002.

Shihab, M. Quraish, Tafsir Al-Misbah, Pesan, Kesan dan Keserasian Al-Qur'an, Vol.2, Jakarta: Lentera Hati, 2002.

Shihab, M. Quraish, Tafsir Al-Misbał, Pesan, Kesan dan Keserasian Al-Qur'an, Vol.5, Jakarta: Lentera Hati, 2002.

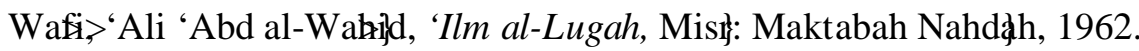

